DOI: $10.4274 /$ tod. 07108

Turk J Osteoporos 2018;24:11-4

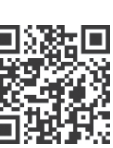

\title{
Assessment of Vitamin D and Inflammatory Response Relationship Using Neutrophil to Lymphocyte Ratio, Platelet to Lymphocyte Ratio and Mean Platelet Volume
}

\author{
D Vitamini ve Enflamasyon Ilişskisinin Nötrofil Lenfosit Oranı, Trombosit Lenfosit Oranı ve \\ Ortalama Trombosit Hacmi ile Değerlendirilmesi \\ Izmir Katip Çelebi University, Atatürk Training and Research Hospital, Clinic of Physical Medicine and Rehabilitation, Izmir, Turkey
}

\section{Abstract}

Objective: Vitamin D is important for calcium and phosphorus metabolism as well as bone homeostasis. Moreover, its receptors were detected in immune system, brain, eyes, pancreas, heart, adipose tissue, thyroid and parathyroid tissues in addition to other tissues and vitamin $\mathrm{D}$ deficiency is thought to play a role in immune system response, autoimmune diseases, infectious diseases, some types of cancers, and cardiovascular and metabolic diseases as well. In this study, our main objective is to assess the relationship between 25 -hydroxy- $\mathrm{D}_{3}$ $\left[25(\mathrm{OH}) \mathrm{D}_{3}\right]$ deficiency and inflammation; using C-reactive protein (CRP), platelet to lymphocyte rate (PLR), neutrophil to lymphocyte ratio (NLR) and mean platelet volume (MPV) parameters.

Materials and Methods: This retrospective-cross-sectional study included 122 patients with diagnosed $25(\mathrm{OH}) \mathrm{D}_{3}$ deficiency and 85 controls. Patients' CRP, NLR, PLR and MPV values were recorded and investigated.

Results: There was no significant difference between the patients with $25(\mathrm{OH}) \mathrm{D}_{3}$ deficiency and control group in terms of NLR, PLR and MPV $(p>0.05)$. However, CRP was significantly higher in $25(\mathrm{OH}) \mathrm{D}_{3}$ deficiency patients $(p=0.001)$. No correlation between the values were detected. Conclusion: In our study, CRP values were significantly higher in patients with $25(\mathrm{OH}) \mathrm{D}_{3}$ deficiencies. However, we were unable to find a significant relationship between $25(\mathrm{OH}) \mathrm{D}_{3}$ deficiency and NLR, PLR and MPV values. In order to assess the relationship between inflammation and vitamin D deficiency properly, well-designed prospective randomized controlled studies with wider series are required.

Keywords: 25-hydroxy- $\mathrm{D}_{3}$, inflammation, C-reactive protein, neutrophil to lymphocyte ratio, platelet to lymphocyte rate, mean platelet volume

\section{Öz}

Amaç: D vitamini kalsiyum ve fosfor metabolizmasında ve kemik homeostazında önemli rol oynamaktadır. Bunun yanı sıra immün sistem, beyin, gözler, pankreas, kalp, yağ dokusu, tiroit, paratitoid gibi birçok doku ve organda reseptörü gösterilmiş ve $D$ vitamini eksikliğinin immün yanıtın düzenlenmesinde, otoimmün hastalıklarda, enfeksiyöz hastalıklarda, çeşitli kanserlerde, kardiyovasküler ve metabolik hastalıklarda da önemli rol oynadığı ileri sürülmüştür. Bu çalışmada 25-hidroksi- $\mathrm{D}_{3}\left[25(\mathrm{OH}) \mathrm{D}_{3}\right]$ eksikliğinin enflamasyonla ilişkisinin nötrofil lenfosit oranı (NLO), trombosit lenfosit oranı (TLO) ve ortalama trombosit hacmi (OTH) parametreleri kullanılarak değerlendirilmesi amaçlanmıştır.

Gereç ve Yöntem: Bu retrospektif-kesitsel çalışmaya 25(OH)D $D_{3}$ eksikliği olan 122 hasta ile 85 kontrol alınmıştır. Hastaların C-reaktif protein (CRP), NLO, TLO ve OTH değerleri kaydedilmiş ve incelenmiştir.

Bulgular: 25(OH) $D_{3}$ eksikliği olan hastalar ile kontrol grubu arasında NLO, TLO ve OTH açısından anlamlı fark saptanmamıştır ( $\left.p>0,05\right)$. 25(OH) $D_{3}$ eksikliği olan hastalarda CRP anlamlı olarak yüksek bulunmuştur $(p=0,001)$. Değerler arasında herhangi bir korelasyon saptanmamıştır.

Sonuç: Çalışmamızda D vitamini eksikliği ile NLO, TLO ve OTH değerleri arasında anlamlı bir ilişki saptanmazken; CRP, D vitamini eksikliği olan hastalarda yüksek olarak bulunmuştur. D vitamini eksikliği ile yüksek MPV arasındaki ilişkiyi düzgün bir şekilde değerlendirmek için, iyi dizayn edilmiş prospektif, randomize kontrollü çalışmaların daha geniş serilerle yapılması gereklidir.

Anahtar kelimeler: 25 (hidroksi) $D_{3}$, enflamasyon, C-reaktif protein, nötrofil lenfosit oranı, trombosit lenfosit oranı, ortalama trombosit hacmi 


\section{Introduction}

Vitamin $D$, which is a member or steroid hormones family, is found in $D_{2}$ and $D_{3}$ forms within the body. Even though it can be obtained with nutrition, the most important vitamin $D$ source for the body is the vitamin $D_{3}$ synthesis from 7-dihydrocholesterol with sun's ultraviolet B rays on the skin tissue. Systemic transportation following synthesis is done by binding of vitamin D-specific binding proteins. In order to become biologically active, first it is changed into 25 -hydroxy- $D_{3}$ $\left[25(\mathrm{OH}) \mathrm{D}_{3}\right]$ form, also known as calcidiol, through hydroxylation with 25-hydroxylase enzyme. The majority of circulating vitamin $D$ is this form with a very little biological activity and a half-life of 15-20 days and it is the form measured in vitamin D level assessments. It goes through another hydroxylation process in kidneys with 1-ahydroxylase enzyme and turned into calcitriol $\left[1,25(\mathrm{OH}) \mathrm{D}_{3}\right]$ form which is biologically active (1).

Lately, the increased time spent indoors without sunlight, sun protection training and increased use of sun blockers are all thought to cause the recent increase in vitamin $D$ deficiency rates (2). In healthy people, normal serum $25(\mathrm{OH})$ $\mathrm{D}_{3}$ concentrations are $30 \mathrm{ng} / \mathrm{mL}$ and above. Serum $25(\mathrm{OH}) \mathrm{D}_{3}$ levels below $<20 \mathrm{ng} / \mathrm{mL}$ is called vitamin $D$ deficiency and levels between $21-29 \mathrm{ng} / \mathrm{mL}$ is defined as vitamin $D$ insufficiency (3). $1,25(\mathrm{OH})_{2} \mathrm{D}_{3}$ is of particular importance regarding calcium and phosphorus metabolism, and therefore, the bone homeostasis. Moreover, its receptors were also found in various tissues among the body such as immune system, brain, eyes, pancreas, heart, adipose tissue, thyroid and parathyroid and its extra-skeletal benefits were reported. Vitamin D deficiency is related with immune response regulation, autoimmune diseases, infectious diseases, various cancers, cardiovascular and metabolic diseases $(1,2,4)$. It was shown that not only active vitamin $D$ receptors can be found within immune cells, but also those cells can locally activate vitamin D as well. Therefore, vitamin D deficiency and its relationship with infections or autoimmune diseases is also a hot topic today (4).

In the studies that research the relationship between vitamin D deficiency and inflammation, the most commonly used inflammation markers are erythrocyte sedimentation rate (ESR) and C-reactive protein (CRP). In the last years, white cell count which is easy, cheap and very practical, is also used for assessment. Neutrophil to lymphocyte (NLR) rate, which can be easily calculated from white cell count, is used as a marker for systemic inflammation presence in various situations such as various cancers, infectious or inflammatory diseases or cardiovascular and metabolic diseases. Its main advantages include the insensitivity to factors such as exercise and dehydration and its easy retrospective calculation $(5,6)$.

Platelets also play an important role in inflammatory response. Mean platelet volume (MPV) is a marker of platelet activation. Increased MPV shows an increase in platelet size and more reactive due to increased platelets platelet cycle (7). In inflammated tissues, MPV showed more higher platelets (8). Thrombocyte-lymphocyte rate (PLR) was also researched in a variety of conditions with inflammation and reported to be connected to inflammation (9).

In this retrospective-controlled study, we would like to research the relationship between $25(\mathrm{OH}) \mathrm{D}_{3}$ deficiency and inflammation using NLR, PLR and MPV in addition to CRP.

\section{Materials and Methods}

After obtaining ethical approval from İzmir Katip Çelebi University, Atatürk Training and Research Hospital's Ethical Committee (approval number: 97), records of patients who presented to physical medicine and rehabilitation outpatient clinics with the complaints of nonspecific muscle or joint pain between the dates of January 2016 to January 2017 were retrospectively reviewed. $25(\mathrm{OH}) \mathrm{D}_{3}$ deficiency was defined as $<20 \mathrm{ng} / \mathrm{mL}$ (3). The patients with infections or inflammations in joints/muscles/soft tissues, restriction in joint range of motions, deficits in neurological examinations, acute or chronic infection signs [abnormal lymphocyte (1000-4800/ $\left.\mathrm{mm}^{3}\right)$, platelet $\left(150.000-450.000 / \mathrm{mm}^{3}\right)$ and white blood cell counts $\left.\left(1500-8000 / \mathrm{mm}^{3}\right)\right]$, acute coronary or cerebral diseases, renal insufficiencies, chronic liver diseases, malignancies, inflammatory diseases, obstructive lung diseases and asthmas were excluded from the study. Age and sex-matched patients with $25(\mathrm{OH}) \mathrm{D}_{3}$ levels $>20 \mathrm{ng} / \mathrm{mL}$ constituted the control group. Similar excusion criterion were applied for control group. After excusion, a total of 112 patients with $25(\mathrm{OH}) \mathrm{D}_{3}$ deficiency and 85 patients without $25(\mathrm{OH}) \mathrm{D}_{3}$ deficiency were included in the study. Demographic values (age and sex), $25(\mathrm{OH}) \mathrm{D}_{3}$ levels, CRP and hemogram results of all patients were recorded.

NLR and PLR were calculated with NLR and thrombocytelymphocyte numbers. MPV was also recorded.

$25(\mathrm{OH}) \mathrm{D}_{3}$ levels were measured using HPLC method in Thermo Scientific machine, CRP was measured using immunoturbidometry in Abbott Architect c16000 and hemogram was measured using Mindray c6800 flowcytometry.

\section{Statistical Analysis}

Statistical evaluation of data was performed using IBM SPSS Statics Version 24. Pearson chi-square test was used to compare the gender differences between groups. Mann-Whitney $U$ or Independent samples t-test was used for comparison of continuous variables according to the distribution of data. The correlations between the variables was assessed by Pearson correlation analysis. $\mathrm{P}<0.05$ was considered as statistically significant.

\section{Results}

Our study included 122 (106 female, 16 male) 25(OH) $\mathrm{D}_{3}$ deficient patients and 85 (77 female, 8 male) controls. Significant difference was found between the groups in terms of mean ages (patient group 48.3, controls 56.8) $(p=0.01)$. There was no significant difference in gender $(p=0.413), P L R$, NLR and MPV values between groups. CRP values were found to be significantly higher in $25(\mathrm{OH}) \mathrm{D}_{3}$ deficiency group than 
in controls $(p=0.001)$ (Table 1$)$. No correlation was detected in-between.

\section{Discussion}

In our study, we were unable to find a significant relationship between $25(\mathrm{OH}) \mathrm{D}_{3}$ deficiency and NLR, PLR and MPV values. $C R P$ values were found to be significantly higher in patients with $25(\mathrm{OH}) \mathrm{D}_{3}$ deficiency.

Although the relationship between $25(\mathrm{OH}) \mathrm{D}_{3}$ deficiency and inflammation is studied in many publications found in the literature, no consensus is present on this subject yet. There are some studies in the literature which report a negative correlation between $25(\mathrm{OH}) \mathrm{D}_{3}$ and CRP (9-16). Yilmaz et al. (13) included 30 hyperemesis gravidarum patients with $25(\mathrm{OH})$ $D_{3}$ deficiencies and 30 healthy controls in their study and reported that hs-CRP levels were higher in $25(\mathrm{OH}) \mathrm{D}_{3}$ deficient group. Alrefai et al. (14) reported that $25(\mathrm{OH}) \mathrm{D}_{3}$ levels were decreased and hs-CRP levels were increased as disease activity increased in 201 patients with Crohn disease. Mathur et al. (15) revealed that CRP levels were decreased in response to vitamin D supplementation in vitamin D deficient patients with ulcerative colitis. Akbas et al's (9) study retrospectively reviewed 4120 patients with $25(\mathrm{OH}) \mathrm{D}_{3}$ deficiency and reported a negative correlation between $25(\mathrm{OH}) \mathrm{D}_{3}$ deficiency with CRP, NLR and PLR values. In addition, they said that easily calculated, practical, repeatable and affordable parameters of NLR and PLR can be used as markers for both inflammation and endothelial dysfunction. Tabatabaeizadeh et al. (16) evaluated the hs-CRP and NRL levels before and after supplementation with vitamin $D$ in 580 adolescent subjects and reported that hs-CRP and NRL levels were decreased after supplementation. They indicated that the NLR could be used to follow-up the inflammation. Mirchi et al. (17) reported a significant relation of $25(\mathrm{OH}) \mathrm{D}_{3}$ with NLR in hemodialysis patients. We also found a negative relationship between $\mathrm{CRP}$ and $25(\mathrm{OH}) \mathrm{D}_{3}$ levels. However, no relation was found between $25(\mathrm{OH}) \mathrm{D}_{3}$ and NLR and PLR values.
Contradictory to our results, few studies reported no relationship between CRP and $25(\mathrm{OH}) \mathrm{D}_{3}$ deficiency (18-20). Yildirim et al's (19) study did a screening of patients with and without chronic kidney disease and compared $25(\mathrm{OH}) \mathrm{D}_{3}$ with $\mathrm{CRP}$, ESR and hemogram values. In the end, they reported no relationship between $25(\mathrm{OH}) \mathrm{D}_{3}$ and inflammation markers. Kim et al's (20) study which researched the relationship between cardiovascular disease underlying factors with $25(\mathrm{OH})$ $D_{3}$ reported no connection between $25(\mathrm{OH}) \mathrm{D}_{3}$ with $C R P$ and interleukin-6.

It is difficult to make a causative relationship between vitamin $D$ deficiency with any disease. The previous studies which reported these relationships seem to be based on evidence from observational studies. In order to certainly relate a disease with vitamin D deficiency, clinical studies which would show an improvement or avoidance of disease with sufficient vitamin D replacement are necessary. The cause for vitamin $\mathrm{D}$ deficiencies detected on some chronical diseases can also be caused by insufficient time spent outdoors or nutritional problems. For this reason, randomized controlled clinical studies with wider series are necessary for this subject $(2,21)$.

Chemokines secreted from activated thrombocyte wall were shown to play a role in immune response by acting like acute phase reactant and worked like neutrophil, granulocyte and monocyte, and even a direct antimicrobial effect (22). Thrombocyte activation is related with inflammatory response and thrombosis. In inflammated tissues, platelets with higher MPV were reported. MPV is a relatively reliable marker for thrombopoietin and platelet functions. High MPV is related with various cardiovascular and cerebrovascular diseases and diseases with low level of inflammation. Recent knowledge tells us a clear relationship between increased MPV and thrombosis risk. Sobolewska et al. (8) used MPV in the assessment of subclinical inflammation and biological treatment response in Crohn's disease patients. High MPV was found to be a good marker which predicts good response to infliximab treatment.

Table 1. Demographic and clinical characteristics of patients with 25(hydroxy)D deficiency and healthy controls

\begin{tabular}{|c|c|c|c|c|}
\hline & Group 1 & Group 2 & $\chi^{2} / z / t$ & p \\
\hline Age & 49 (19-75) & $58(19-80)$ & -4.988 & $<0.001$ \\
\hline Vitamin D & $12.35(4.1-57)$ & $32.9(25.2-200)$ & -11.736 & $<0.001$ \\
\hline CRP & $0.29(0.02-26.5)$ & $0.17(0.02-8)$ & -3.320 & $<0.001$ \\
\hline ESR & $17(2-62)$ & $12(5-50)$ & -2.895 & 0.004 \\
\hline Neutrophil & 3.78 (1.91-11.39) & $3.76(0.21-8.54)$ & -0.397 & 0.691 \\
\hline Lymphocyte & $2.19 \pm 0.71$ & $2.2 \pm 0.65$ & -0.148 & $0.883^{*}$ \\
\hline PLT & $268.5(42-661)$ & $257(131-424)$ & -0.997 & 0.319 \\
\hline$N / L$ & $1.89(0.65-14.59)$ & $1.75(0.68-20.33)$ & -0.547 & 0.584 \\
\hline$P / L$ & $124.86(18.75-968.18)$ & $122.4(58.53-677.42)$ & -0.609 & 0.543 \\
\hline MPV & $10.2(8-13.5)$ & $10.3(7.7-13)$ & -1.271 & 0.204 \\
\hline
\end{tabular}

Mann-Whitney $U$ analysis, *Independent sample t-test

CRP: C-reactive protein, ESR: Erythrocyte sedimentation rate, NLR: Neutrophil to lymphocyte ratio, PLR: Platelet to lymphocyte rate, MPV: Mean platelet volume, $x^{2}$ : Chi-square, $z$ : Mann-Whitney $U$ test, t: Independent sample t-test 
Çerman Aksu et al's (7) study on psoriasis patients assessed the relationship between disease severity with NLR and MPV and found no significant relationship between those markers. Beyan et al. (23) reported that MPV alone was insufficient to demonstrate platelect activation. We also did not find any relation between MPV and $25(\mathrm{OH}) \mathrm{D}_{3}$ deficiency.

\section{Study Limitations}

The major limitation of our study is its retrospective design and small number of patients and controls. Another important limitation is that the controls were not chosen from healthy volunteers, but from the patients presented with nonspecific joint or muscle pain. Prospective randomized studies including healthy controls will yield more accurate results. Other limitations include other factors which might affect $25(\mathrm{OH}) \mathrm{D}_{3}$ levels and MPV, NLR and PLR values such as obesity, smoking, lipid levels, seasonal changes and reasons for hospitalization. The significant difference between the mean ages of patient and control groups might also affect the outcome results.

\section{Conclusion}

To conclude, CRP was found to be higher in patients with $25(\mathrm{OH}) \mathrm{D}_{3}$ deficiency, however we were unable to detect a significant relationship between $25(\mathrm{OH}) \mathrm{D}_{3}$ deficiency with other inflammation markers including NLR, PLR and MPV. Prospective randomized studies including larger number of subjects are needed to interprete the relation between $25(\mathrm{OH}) \mathrm{D}_{3}$ deficiency and inflammation more accurately.

\section{Ethics}

Ethics Committee Approval: This study was approval İzmir Katip Çelebi University, Atatürk Training and Research Hospital's Ethical Committee (approval number: 97).

Informed Consent: Retrospective study.

Peer-review: Externally and internally peer-reviewed.

\section{Authorship Contributions}

Concept: E.U.A., Design: E.U.A., Data Collection or Processing: E.U.A., Analysis or Interpretation: E.U.A., A.T., Literature Search: E.U.A., A.T., Writing: E.U.A., A.T.

Conflict of Interest: No conflict of interest was declared by the authors

Financial Disclosure: The authors declared that this study received no financial support.

\section{References}

1. Kocovska E, Fernell E, Billstedt E, Minnis H, Gillberg C. Vitamin D and autism: clinical review. Res Dev Disabil 2012;33:1541-50.

2. Theodoratou E, Tzoulaki I, Zgaga L, loannidis JP. Vitamin D and multiple health outcomes: umbrella review of systematic reviews and meta-analyses of observational studies and randomised trials. BMJ 2014;348:g2035.

3. Holick MF, Binkley NC, Bischoff-Ferrari HA, Gordon CM, Hanley DA, Heaney RP, et al. Evaluation, treatment, and prevention of vitamin D deficiency: an Endocrine Society clinical practice guideline. J Clin Endocrinol Metab 2011;96:1911-30.
4. Baeke F, Takiishi T, Korf H, Gysemans C, Mathieu C. Vitamin D: modulator of the immune system. Curr Opin Pharmacol 2010;10:482-96.

5. Bhat T, Teli S, Rijal J, Bhat H, Raza M, Khoueiry G, et al. Neutrophil to lymphocyte ratio and cardiovascular diseases: a review. Expert Rev Cardiovasc Ther 2013;11:55-9.

6. Isaac $V, W u C Y$, Huang $C T$, Baune BT, Tseng CL, McLachlan CS. Elevated neutrophil to lymphocyte ratio predicts mortality in medical inpatients with multiple chronic conditions. Medicine (Baltimore) 2016;95:e3832.

7. Çerman Aksu A, Aktaş Karabay E, Altunay Kivanç I. Psoriazisli Hastalarda Nötrofil Lenfosit Orani ve Ortalama Trombosit Hacminin Degerlendirilmesi. Şşşli Etfal Hastanesi Tıp Bülteni 2016:50:137-41.

8. Sobolewska A, Włodarczyk M, Stec-Michalska K, Fichna J, Wiśniewska-Jarosińska M. Mean Platelet Volume in Crohn's Disease Patients Predicts Sustained Response to a 52-Week Infliximab Therapy: A Pilot Study. Dig Dis Sci 2016;61:542-9.

9. Akbas EM, Gungor A, Ozcicek A, Akbas N, Askin S, Polat M. Vitamin $D$ and inflammation: evaluation with neutrophil-tolymphocyte ratio and platelet-to-lymphocyte ratio. Arch Med Sci 2016:12:721-7.

10. Ngo DT, Sverdlov AL, McNeil JJ, Horowitz JD. Does vitamin D modulate asymmetric dimethylarginine and C-reactive protein concentrations? Am J Med 2010;123:335-41.

11. Eleftheriadis T, Antoniadi G, Liakopoulos V, Stefanidis I, Galaktidou G. Inverse association of serum 25-hydroxyvitamin D with markers of inflammation and suppression of osteoclastic activity in hemodialysis patients. Iran J Kidney Dis 2012;6:129-35.

12. Ashraf AP, Fisher G, Alvarez J, Dudenbostel T, Calhoun DA, Szalai AJ, et al. Associations of C-reactive protein to indices of vascular health and the influence of serum 25(OH)D status in healthy adults. J Nutr Metab 2012:2012:475975.

13. Yılmaz S, Akdağ Cırık D, Demirtaş C, Timur H, Şahin A, Danışman $N$, et al. Do vitamin $D$ and high-sensitivity-C reactive protein levels differ in patients with hyperemesis gravidarum? A preliminary study. Turk J Obstet Gynecol 2016;13:123-6.

14. Alrefai D, Jones J, El-Matary W, Whiting SJ, Aljebreen A, Mirhosseini N, et al. The Association of Vitamin D Status with Disease Activity in a Cohort of Crohn's Disease Patients in Canada. Nutrients 2017:9

15. Mathur J, Naing $S$, Mills $P$, Limsui $D$. A randomized clinical trial of vitamin D3 (cholecalciferol) in ulcerative colitis patients with hypovitaminosis D3. Peer J 2017;5:e3654.

16. Tabatabaeizadeh SA, Avan A, Bahrami A, Khodashenas E, Esmaeili $H$, Ferns GA, et al. High Dose Supplementation of Vitamin D Affects Measures of Systemic Inflammation: Reductions in High Sensitivity C-Reactive Protein Level and Neutrophil to Lymphocyte Ratio (NLR) Distribution. J Cell Biochem 2017;118:4317-22.

17. Mirchi E, Saghafi H, Gharehbeglou M, Aghaali M, Rezaian Z, Ghaviahd M. Association Between 25-Hydroxyvitamin D Level and Inflammatory and Nutritional Factors in Hemodialysis and Peritoneal dialysis Patients in Qom, Iran. Iran J Kidney Dis. 2016;10:205-12.

18. Garcia-Bailo B, Josse AR, Jamnik J, Badawi A, El-Sohemy A. Positive association between 25-hydroxyvitamin $D$ and C-reactive protein is confounded by hormonal contraceptive use. J Womens Health (Larchmt) 2013;22:417-25.

19. Yildirim I, Hur E, Kokturk F. Inflammatory markers: C-reactive protein, erythrocyte sedimentation rate, and leukocyte count in vitamin $\mathrm{D}$ deficient patients with and without chronic kidney disease. Int J Endocrinol 2013:2013:802165.

20. Kim M, Na W, Sohn C. Correlation between vitamin D and cardiovascular disease predictors in overweight and obese Koreans. J Clin Biochem Nutr 2013;52:167-71.

21. Reid IR. What diseases are causally linked to vitamin $D$ deficiency? Arch Dis Child 2016;101:185-9.

22. Flad HD, Brandt E. Platelet-derived chemokines: pathophysiology and therapeutic aspects. Cell Mol Life Sci 2010;67:2363-86.

23. Beyan C, Kaptan K, Ifran A. The relationship of mean platelet volume with the risk and prognosis of cardiovascular diseases. Int J Clin Pract 2010;64:827-8. 